Journal of Urban and Regional Analysis, vol. XIII, 1, 2021, p. 145 - 161

https://doi.org/10.37043/JURA.2021.13.1.9

\title{
THE URBAN POOR IN DHAKA: PERSPECTIVES ON THE RIGHT TO THE CITY
}

\author{
Shamsul AREFIN, Tamanna RASHID \\ Bangabandhu Sheikh Mujibur Rahman Science and Technology University, \\ Dhaka, Bangladesh
}

\begin{abstract}
The urban poor experience serious discontents, harassment, eviction, police repression and local goons threatening when using urban space for living and livelihood purposes. This study pursues to understand the poor people's negotiation strategies with different powerful agents who occupy money, muscleman and political affiliation. Following a mixed method approach, this study investigates the two biggest slums in Dhaka as case studies. Findings show that urban poor have to build different social-contract relations with various local agents as survival mechanisms while economic activities using urban space are considered to be illegal in Bangladesh. The role of the state is somewhat ambiguous in this regard. On the one hand, the state is not evicting the poor permanently from the city but it is repatriating them on other grounds and, on the other hand, it permits hundreds of informal intermediary agents to work for sustaining informal urban settlements for the poor people. We argue that these distinctive socio-structural arrangements in Dhaka city is hindering poor people from getting united and claiming their rights to the city while also not providing them proper opportunities to fully appropriate the urban space. These socioeconomic relations need to be considered in order to make a just city for all, from the RTC perspective.
\end{abstract}

Key Words: urban space, right to the city, appropriation of space, urban poor, gendered space.

\section{Introduction}

Dhaka has emerged as one of the fastest growing megacities in the world with an annual growth rate of 4.4 percent (UN-HABITAT 2008, Arefin 2018). The city holds a striking population of 17 million currently and it is projected to be over 27 million by 2030 (Ahmed 2014, Mohiuddin 2014). It is estimated that about $35 \%$ people live below the poverty line in Dhaka city while nearly $20 \%$ of them were classified as living in hardcore poverty in more than 4000 slums or informal settlements throughout the city (Islam 2005). Other studies reveal that more than one third of the approximately 12 million inhabitants of Dhaka live in bosti ${ }^{1}$, informal or irregular settlements developed on different private and public lands (World Bank 2007, Government of Bangladesh 2008, Hossain 2011, Hackenbroch and Hossain 2012). The global triumph of neoliberal policies as well as the accelerated rate of urbanization has greatly changed the ruralurban structure, creating a massive trend of migration to city areas. Being the hub of all kinds of socio-economic, cultural and political activities, Dhaka experiences approximately 300,000400,000 new comers each year (WSUP 2017), which is, therefore, creating enormous pressure on its limited space. Providing space for living and livelihood activities to this ever increasing population has become as challenging as bringing them in all necessary social services. As a result, conflicts over using urban spaces have become regular phenomena in Dhaka, like in all other cities of the global south (Lata et al. 2019).

In the cases of Mumbai and Chennai, as urban space has become very contentious, lives and livelihoods of the urban poor in informal settlements have become increasingly problematic

1) A slum or bosti is a residential area with substandard housing that is poorly serviced and/or overcrowded, and therefore unhealthy, unsafe and socially undesirable. 
(Phadke 2007, Mohan 2017). Furthermore, the marginalized Romani people of Szeged, Hungary, pose an example of extreme poverty, a lack of subsistence and job opportunities, poor and uncertain housing conditions, inability to provide education for their children and everyday discrimination (Málovics et al. 2019). Likewise, poor slum dwellers in Dhaka, who are also vulnerable for their tenuous day to day position in the urban space, have to sustain their livelihoods in flexible and precarious types of informal "street economy" (Etzold and Keck 2009, Etzold et al. 2009).

The proliferations of street economy, as well as the conflicts between street vendors and a range of formal and informal intermediary actors, are increasingly making urban spaces a matter of appropriation and contestation. Urban poor in many cities, particularly in Latin America, have established examples of successful movements through their organized and collective efforts (Crossa 2009, Mackie et al. 2014). But in the case of Dhaka, although vendors are a regular subject to exploitation, coercion and impendence, they are not united for claiming their rights; they rather prefer alternative ways to sustain their activity in cities by negotiating with different agents (Hackenbroch et al. 2016, Lata et al. 2019).

However, in this context, this study conducts Sattola and Pallabi, two informal settlements in Dhaka city, as case studies to explore every day experiences of slum dwellers while using urban spaces mainly for making a living. We will proceed with empirical data by analyzing the nexus between street vendors, local powerful agents and the state's role in making these informal uses of urban space long lasting, albeit through frequent displacement and dispossession. We argue that this peculiar socio-political arrangement of Dhaka city is providing urban poor with uncertain and vulnerable opportunities for living while also preventing them to get organized and claim their rights to the city. Therefore, these localized arrangements and social relationships need to be considered in order to understand social and economic realities, to make an egalitarian city and to develop more pragmatic poverty reduction strategies.

Against this backdrop, the next section firstly contextualizes urban space and the 'Right to the City' along with various protests of the urban poor for claiming their 'Right to the City' across the world. Then, it is followed by a short description of the participants and the detailed methods of the study. Again, it then presents the empirical findings by examining the experiences of urban poor people in Dhaka while accessing urban space in and out of the informal settlements. The article then concludes with a discussion of the urban space, the negotiation process and the absence of protest in claiming their rights over the production of space in Dhaka city.

\section{Contextualizing urban space}

Lefebvre (1991) proposed a conception of space assuming it from three realities: spatial practice (perceived space which arises out of everyday realities), representations of space (i.e. conceived space and represented space), and representational space (i.e. spaces experienced through images and symbols, the spaces of passion and action). The notion of urban space includes what he calls perceived space, conceived space and lived space while lived space "is the complex combination of perceived and conceived space. It represents a person's actual experience of space in everyday life" (Lefebvre 1991: 39). Harvey (1973) also propounded a tripartite conceptualization of space. According to him, "space is neither absolute, nor relative, nor relational in itself, but it can become one or all simultaneously depending on the circumstances and on human practice" (Harvey 1973: 13). However, Santos Junior (2014), combining both Lefebvre and Harvey, offered a more simplistic view of urban space. To him, space may be considered as space within a city which is for public use as well as a collective possession and it also belongs to the authority of the public or to the society as a whole (Santos Junior 2014). Spaces can be of a variety of uses, such as (Santos Junior 2014): 
spaces for circulation (street or square), spaces for leisure and reaction (urban park or garden), spaces for contemplation (such as waterfall), and spaces designated for preservation or conservation (such as ecological reserve). He further distinguished between the public and the private space as:

"the concept of public space or the public sphere is distinguished from the private sphere and refers to spaces of public interest (Bobbio 2006), spaces constituted of identities and collective action (Sader 1988), spaces that allow societal representation and collective expression (Dahl 1997), spaces for political freedom (O'Donnell 1999), spaces advancing the condition of equality (Arendt 1981), and spaces reflecting democratic formation of opinion and public will (Habermas 1997)" (Santos Junior 2014: 148).

However, urbanization under capitalism involves the creation and destruction of common spaces in cities which is necessary for the production and reproduction of capital. But the use of public space in everyday life also implies a process of negotiations between different actors (Hackenbroch 2013a) because space is the ultimate locus and medium of struggle and it has therefore become a crucial political issue (Elden 2007). Seeing access to space as a product of negotiations needs an analysis of the concept of power and power relations among different actors (Hackenbroch 2013b). Social groups may vary according to their uses, values and meanings when accessing spaces but such differences may arise so many tensions and contradictions among individual and social purposes of using spaces, among the state as well as other forms of dominating social power (Lata and Walters 2016, Sharp et al. 2000). As a result, the poor, the unprivileged and those marginalized from political power suffer first and foremost from the dispossession process (Harvey 2007, Harvey 2009). Power and power relations are dispersed throughout the society (Sharp et al. 2000), and they imply that the poor and the most vulnerable do indeed possess an agency in that they "always seek to negotiate options that help to secure their livelihoods" (Bohle 2007: 130). But referring to Foucault, Sharp et al. (2000) outlined that power does not only refer to domination, but it also refers to the ability to resist.

Therefore, public spaces are experienced as much materially as they are intellectually, and as well as emotionally, and they need to be considered thereby. In this study, the urban common space for the urban poor is treated as space for physical, mental and social activities and relations through the appropriation and participation of decision making over the production of spaces.

\section{Framing the right to the city}

The Marxist social scientist Henry Lefebvre (1968) developed the concept of the 'right to the city' and he used it to mean an urge for all inhabitants in the city to contribute to the "production of urban space" (Lefebvre 1991) and to appropriate its uses (Zérah et al. 2011). Later, his concept was more elaborated and contextualized to the contemporary urban scenario by another neo-Marxist thinker, David Harvey. According to Lefebvre $(1968,2009)$, it is a political program that aims to strengthen the ability of urban dwellers, regardless of their citizenship, ethnicity, ability, gender and so forth, to take part in the process of spatial production in the city (Purcell 2002, Purcell 2003). The right to the city is viewed to be a critique and counter narrative to the neo-liberal economic reforms of the capitalist mode of production that has altered the nexus between the state, the private sector and the civil society around the world (Zérah et al. 2011). Therefore, the right to the city entails the need to restructure the power relations in the production of urban space and it claims to shift the control from the state to the urban inhabitants (Purcell 2002: 102).

To Lefebvre (1996), the right to the city is to be achieved through two action plans: the right to participation and the right to appropriation. The right to participation allows all inhabitants, not 
just legal citizens of a city, to take part in the decision making that shapes the urban spatial and social conditions (Lefebvre 1996, Anderson 2014). By their participation in the decision-making process, the inhabitants living in the city can take control of their city life through appropriation. For Lefebvre (1996), 'appropriation' includes the right of the inhabitants to physically access, occupy and use the urban spaces and, hence, this notion has been the primary focus of the advocates of the right to the city in the case of the urban poor (Arefin 2018). Moreover, Holston (2008) argues that the focus of this approach needs to be shifted from the right to 'the needs of the urban poor' to 'the rights of the citizens', even by bringing changes to the set of available rights when they no longer reflect the justified necessities of citizenship. Therefore, Fernandes (2007: 208) stresses: "The right to the city consists of the right of all city dwellers to fully enjoy urban life with all of its services and advantages - the right to habitation - as well as taking direct part in the management of cities - the right to participation". Purcell (2003) coined a similar term to mean that the urban citizens (including government, private, as well as supra governmental agents) should have a direct say in all decisions which produce and configure the urban space (Plyushteva 2009).

More recent researchers relate the notion of the right to the city to the poverty reduction approach in a context of globalized urbanization. According to Parnell and Pieterse (2010), understanding the all-encompassing criteria of the notion of the right to the city, from civil and political to more collective rights, such as the right to urban services (Arefin and Rashid 2018), helps to develop more pragmatic government interventions to achieve poverty reduction goals (Parnell and Pieterse 2010, Zérah et al. 2011). Therefore, the concept of the right to the city can be traced from individual rights to collective rights, as well as corporate rights, to shape the city with active participation and decision making by all its citizens.

\section{Social movements and the right to the city}

The Right to the city movements along with anti-globalization and global justice movements appeared as a re-action to the commercialization of space and the creation of city as part of the market economy under the neoliberal economic reform (Brenner et al. 2012). Since 1960s, cities like London, Melbourne and Toronto experienced an influx and the settlement of a new class of middle income residents into the city centre as a result of the gentrification process (Smith and Williams 1986, Ley 1996, Tonkiss 2005), which eventually caused eviction, homelessness and the displacement of lower income people from their places (Centre for Urban Studies 1964, Lancione 2017). As a result of this process of gentrification, in the United States it is found that the historically Latino Mission neighbourhood went from being 50 percent Latino in 2000 to almost 38.9 percent in 2013 while in that same time period the number of black population in San Francisco was reported to decrease from 60,500 to just 48,000 people (Lees and Phillips 2018). Similarly, cities like Mumbai, Rio de Janeiro, Jakarta and Lagos are adopting models for making more clean and green cities by re-building their city structures (Samara et al. 2013, Lata 2020a). However, in most cases, when implementing such kind of urban renewal and refurbishment projects, the urban poor people's access to urban spaces for living, livelihood and all other services is severely being neglected. Displacing the poor from the city spaces, nevertheless, has now widely been addressed and challenged by the vanguards of the right to the city movements as Holston (2011: 336) rightly argued: "marginalized groups are shifting from a framework of 'declaring needs' to a framework of demanding those needs as rights".

Powerful nations like USA and China, as well as powerful governments, are always found to be in constant opposition with marginalized groups and they rarely acknowledge equal rights to the city for all urban citizens. But this was possible in the context of Latin America and of some European countries where the political movement won its place on the UN's New Urban Agenda as the 'World Charter for the Right to the City' (Colau 2016). The right to the city movements incorporate a range of diversified agendas of the urban social movements that 
have emerged in several countries, especially in Latin America, such as the movements against evictions, homelessness and the urban reform; for better sanitation, environmental justice and free public transport; the rights of the immigrants and cultural movements (Siddiqui 2008, Grill 2012, Santos Junior 2014). The Brazilian government was the first to initiate the making of a 'just city' for its citizens in 2001 , by enacting the City Statue law to recognize the right to the city as a collective right (Fernandes 2007, Lata 2020b). In Mexico City, the shortage of housing for its citizens has created immense pressure on the real estate companies to implement redevelopment projects which eventually has marginalized low income residents and it pushed them toward the periphery of the city (Adler 2015). Consequently, informal settlements continued to proliferate while 50 percent of the population lacked access to municipal services like water and electricity (Adler 2015). Out of this massive segregation, the Right to the City movement sprung up by a collection of citizen groups that organized the city's marginalized groups along with some non state actors like NGOs (Adler 2015). As a result, the Mexican government posed the Right to the City Charter in 2010, emphasizing more on some core principles of urban governance, such as sustainability, democracy, equity, social justice and equal city rights for every citizen (Adler 2015).

Another successful right to the city movement was the Movimiento de Pobladores en Lucha (MPL) in Chile (Machabanski 2013). MPL, an organization of urban poor working class people, has been working since 2006 and it has now grown to be a nationwide organization working against the displacement and housing insecurity of the urban poor (Machabanski 2013, Arefin 2018). Machabanski (2013) argues that this organization, however, through the empowerment and the increased participation of the marginalized urban poor, has managed to reclaim space and to build community in a way that is paving the road for the production of a dignified habitat for all. Besides, the efforts of MPL made possible long term solutions to the exclusionary institutionalized systems of urban planning and development projects by bringing poor working people into the ownership rights and decision making process. So, the most remarkable work of MPL is the transformation of impoverished victims (of displacement) into empowered citizens. Besides, the recent protest of Romanian commoners against the shale gas extraction was a successful attempt against the neoliberal agenda for central and Eastern Europe (Vesalon and Cretan 2015). The slogan - 'We are not the Wild West of American Investors' during the protest made by the Romanians constructs the public opinion on the social control of natural resources (Vesalon and Crețan 2015). Again, the protest made by the common people of Bucharest in Romania against the corrupted government and political elite after the Colectiv fire in October 2015 is the momentum where protesters used the urban space and the city centre location for a spontaneous action against the governing system, including deep rooted injustice and corruption, state repression, stolen election and grievances, to establish their right to the city (Crețan and O'Brien 2020). Similarly, in the context of south Asian countries, the street vendors of Delhi, Gujarat and Mumbai in India have successfully achieved their vending rights through law enforcement by collective political actions under organizations like NASVI and SEWA (Jhabvala 2010, Alva 2014, Roever 2016).

However, in Dhaka, the urban space assumes more importance as it becomes increasingly appropriated, unequal and contested (Mohan 2017), as Lefebvre (1991) argued that the space is becoming a central object of political struggle in the contemporary world (Haque 2012, Arefin 2018). In his work, Lefebvre (2009) suggested that just as everyday life has become colonized by capitalism, so too has its location-social space (Ross 1988) and there is therefore work to be done on understanding space and how it is socially constructed and used (Elden 2007). Therefore, the urban space in Dhaka has become the most political economy that is necessarily linked with the capitalist development. The production of urban space in Dhaka (Hossain and Hackenbroch 2019), therefore, has become the strategy of "accumulation by dispossession" ${ }^{2)}$ (Harvey 2003, Harvey 2004) in the urbanization process that is obstructing the common people's right to the city. The city embodies the individual command of resources at 
the expense of collective rights to common city dwellers and as a result the poor, the underprivileged, and the marginalized people in the city suffer the most, both socially, economically and politically (Harvey 2003, Harvey 2008). So, the concept of the 'right to the city' of the urban poor, as proposed by Lefebvre (1996) and Harvey (2008), seen as their right to appropriate and to participate in the decision-making process over the production of urban spaces, is always contentious, debated and superficially articulated.

\section{Methodology}

\section{Participants}

The study covers two selected areas of Dhaka City, which is densely populated by the slum dwellers, known as Sattolla and Pallabi (Fig. 1). For this study, 180 respondents were purposively taken from both these areas and among the respondents a fair distribution of male $(52.2 \%)$ and female $(47.8 \%)$ was studied. Most of the respondents belong to the age category of $25-54$ which is near about $58 \%$ and the youth (15-24) and the elderly (55-60+) segment of population covers about $26.11 \%$, and $16.66 \%$, respectively (Table 1 ). Again, the study depicts that about $41 \%$ of the respondents had no education and, moreover, it was found that around $49 \%$ of the respondents had only elementary education and only a few had some secondary $(7.8 \%)$ and above secondary $(2.8 \%)$ education. Also, around $52.8 \%$ of the total respondents were engaged in various informal activities, whereas another $16.1 \%$ of the respondents were engaged in private sectors. Moreover, about $2.22 \%$ of the respondents were engaged in government jobs and another $6.7 \%$ respondents were unemployed. Again, $7.2 \%$ of the respondents are involved in business and the rest of them are housewives $(11.7 \%)$ and students $(3.33 \%)$. Furthermore, the study also reveals that almost $85 \%$ slum dwellers of this study are migrants, whereas only $15 \%$ are local inhabitants of the city.

\section{Data Collection Technique and Analysis}

In 2016 and 2017, the authors conducted a research on the urban slum dwellers of two densely populated slums: Sattola at Mohakhali, and Pallabi at Mirpur-12, in Dhaka city. The aim of the study was to know the urban poor people's access to urban spaces for everyday life and their ways of negotiation with different stakeholders as survival mechanisms. The study areas were purposively selected because of some important reasons. Both slums are among the densely populated slums in Dhaka; Sattola has nearly 12,893 households (Roy et al. 2014, Marcil et al. 2016, Lata et al. 2019) and more than 12,000 households are estimated to be located in Pallabi (Rokanuzzaman et al. 2013). Moreover, both areas represent geographically varied contexts. Pallabi is situated in the Dhaka North City Corporation which is also far from the city centre, while Sattola is in the Dhaka South City Corporation and it is also close to the city centre. However, the most decisive feature is that both areas are juxtaposed with more affluent neighborhoods.

The findings of this study are based on empirical data collected through a combination of a survey, in-depth interviews, observations, and field notes. The survey recruited over 180 respondents (94 males and 86 females) from both areas, through a semi-structured questionnaire, particularly to explore socio-economic and demographic characteristics, as well as to understand the patterns, objectives and problems of using the urban spaces by the urban poor people. In-depth interviews were carried out with 14 informal workers and 2 local

Accumulation by dispossession is a concept presented by the Marxist geographer David Harvey (2004). It defines neoliberal capitalist policies that result in a centralization of wealth and power in the hands of a few by dispossessing the public and private entities of their wealth or land (Harvey 2004). Such policies are visible in many western nations from the 1970s and to the present day. Harvey (2004) argues that these policies are guided by four principles: privatization, financialization, management and the manipulation of crises and state redistributions. 
The Urban Poor in Dhaka: Perspectives on the Right to the City

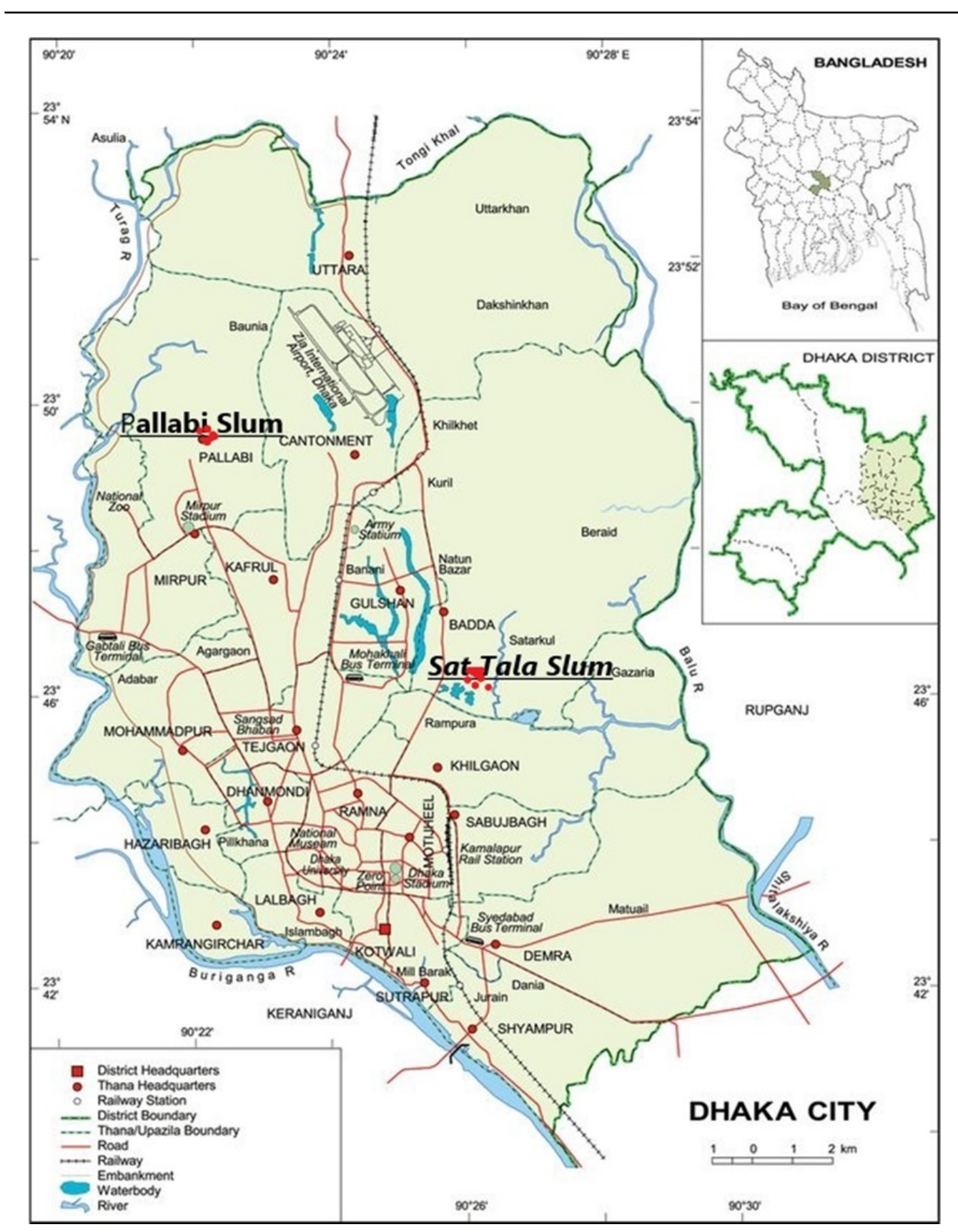

Fig. 1 - Location and administrative map of Dhaka City, with Pallabi and Sattala slum Source: Swapan et al. (2017) 
Demographic profile of the respondents

\begin{tabular}{|c|c|c|c|}
\hline Variables & Indicator & Sample (n) & Percentage (\%) \\
\hline \multirow[t]{2}{*}{ Gender } & Male & 94 & 52.2 \\
\hline & Female & 86 & 47.8 \\
\hline \multirow[t]{3}{*}{ Age } & $15-24$ & 47 & 26.11 \\
\hline & $25-54$ & 103 & 57.22 \\
\hline & $55-60+$ & 30 & 16.66 \\
\hline \multirow[t]{5}{*}{ Education } & No schooling & 74 & 40.6 \\
\hline & Primary school & 88 & 48.9 \\
\hline & Secondary school & 14 & 7.8 \\
\hline & Graduate & 4 & 2.2 \\
\hline & Post-Graduate & 1 & 0.6 \\
\hline \multirow[t]{7}{*}{ Occupation } & Unemployed & 12 & 6.7 \\
\hline & Business & 13 & 7.2 \\
\hline & Govt. service & 4 & 2.2 \\
\hline & Private service & 29 & 16.1 \\
\hline & Informal job & 95 & 52.8 \\
\hline & Student & 6 & 3.3 \\
\hline & Housewife & 21 & 11.7 \\
\hline \multirow[t]{2}{*}{ Migration Status } & Yes & 153 & 85 \\
\hline & No & 27 & 15 \\
\hline
\end{tabular}

Source: Field Survey (2016-2017)

government stakeholders. The themes covered in the in-depth interviews were: urban social services available to the poor, the appropriation of space, eviction, as well as displacement, negotiation strategies, claiming the right to the city and the role and responsibility of local government officials. In addition to the interviews, the researchers spent a substantial amount of time observing the everyday activities of informal workers and their interaction with other agents in the study settings. Furthermore, the researchers were involved in numerous informal discussions with slum people in order to verify the information collected through other research tools.

Qualitative data were analyzed using an open coding approach until significant typologies and categories emerged from the data. Besides, quantitative data were coded and entered into IBM SPSS 24 for statistical analysis and tabular presentation, while bivariate and cross tabulations were operated. This study combines both methods for collecting and analyzing data so that a solid picture of the everyday life, the struggle and the mechanisms of survival of the informal workers can be generated.

\section{Results}

\section{Appropriation of urban common spaces}

The city's common spaces are appropriated by the capital which is necessary for the production-reproduction of capitalist relations in the contemporary neoliberal cities (Santos Junior 2014). Dhaka, a neo-capitalist hub of accelerating capital, is experiencing such scenarios over the urban space in the name of 'creative destruction', as proposed by Harvey 
(2008). So, the question which comes first is: 'how do the urban poor utilize the everyday urban spaces when space becomes a means of constant contentious and a mode of capitalist production?'.

In the context of Dhaka, it was found that most of the urban poor living in various slums are involved in the informal economy as rickshaw pullers, street vendors, hawkers (i.e. roadside business), garments workers etc., which is the only source of livelihood for them (Ishtiaque and Mahmud 2011). From this study, it was found that among those who are engaged in different types of occupations, around $52.85 \%$ are engaged in informal activities, as their education supports less for formal activities. As a result, in most of the cases they had to utilize different public spaces like streets, neighborhood locality, transportation, park etc. in the cities for doing their everyday task. But, as space becomes vital for the capitalist and also for the urban poor, contradictions are always found over the control of the space which restricted the urban poor's movement over the space. This study depicts that about $43.8 \%$ of the respondents couldn't use the same space every day and about $53.3 \%$ respondents faced various difficulties, including public harassment, police repressions, local mastans threatening and frequent evictions from one place to another. In an interview with Md. Kabir Hossain, a 45 years old fisherman, currently doing business at Mohakhali Wareless gate from Sattala Slum, the researchers evidenced the frequent movements of the informal workers from one place to another. To his utterance:

"When I started with this business (fish selling), I had no capital. I used to live under the open space and had no permanent space to use. Every day I had to face various problems while using public spaces. Then a few months later, I got this free space. But I couldn't enjoy using this space a long time because a multi-storied apartment building was built here within a few months. Again, after some days, a man came to me and ordered to pay 3500 taka monthly fees if I want to continue using this space".

Zakaria Ahmed, a 42 years old rickshaw puller living in Pallabi Slum at Mirpur-12, also shares similar experiences while driving rickshaws in various public spaces in the city:

"I could drive the rickshaw from Pallabi to anywhere within the city. But now, I couldn't drive the rickshaw on VIP roads. The police threatened us. Sometimes they took away our mattress covers and demanded money. They never filed any case against us if we violate any law; rather they demand 200-300 taka for every mattress cover from us. They called this bribery as pocket money".

\section{Gendered urban space}

This study also revealed that the appropriation of space is a gender based issue. About $57.0 \%$ of the female respondent who utilize public spaces in everyday life had to face many obstacles which restricted their movement within the space. From the in-depth interview, it was found that in most of the cases female garment workers had to face harassments by the strangers and sometimes by their male colleagues as well as by the stalkers of the neighborhood locality. Shayla, 21 years old garments worker from the Pallabi slum, shares her experiences in this regard:

"It is difficult to move after the evening comes. Stalkers are everywhere in this locality. If anyone moves alone on the streets in the evening, she will certainly be harassed by these stalkers".

In a recent work in Sattola slum in Dhaka, Lata (2020a) found that women bear the triple burden of social stigma, religious barriers and patriarchy in accessing the public space to earn an income (Fattah and Walters 2020). Even the elderly women who earned a living for the 
families' survival faced sexual and verbal harassment and other types of harassment and maltreatment. Besides, some women expressed that sometimes men treat them as sex workers because they occupied the street for doing business. A similar context is prevailed in the Indian society where women face specific constrains when it comes to accessing the urban space and other urban resources; young women, poor women, women of religious minorities and women with disabilities - they all are equally vulnerable (Lama-Rewal 2011).

\section{Negotiation over the urban space}

Urban space is socially constructed and, as a result, different stakeholders have different interests, needs and aspirations and a differential power to dominate the space. As the appropriation of public spaces for selling products is formally illegal in Dhaka (Lata 2020c), the urban poor had to negotiate with different agencies to continue their business within the slum and outside the slum. In this study, it was revealed that the urban poor people's negotiation began with this powerful elite who has money, musclemen and political affiliation. Sometimes, their negotiation process ended with giving a space fare in every month, and sometimes they had to give a donation to the line men and local mastans, as well as to police staff.

Shafiqul Islam, 38 years old, inhabitant of Pallabi Slum at Mirpur, living in this slum for the last 15 years, illustrated the mechanism process within the slum. He concurs as:

"I know this is a government land. But, in this slum, the local MP controlled everything. So we had to pay 600-800 taka as space fees in every month to the follower of MP so that we may survive in this slum".

This study also reveals that people who have a good networking with the community leaders and the local gang can easily get access to space within the locality. Eshan (28), a food vendor from the Sattola slum at Mohakhali, said:

"In this slum, we have a committee. In that committee, we have community leaders. If anyone wants to do business and needs any space in this slum, he/she had to manage our leaders. If he allows him/her, then he/she can do business here. But he/ she must be a local resident of this slum".

Lata and Walters (2016) have also seen that the residents of Sattola who have a strong kin network or social network are powerful. Apart from this, sometimes the slum dwellers willingly gave bribe to different channels in the name of tenure security. While talking with Enayet Hossain, a 30 years old street hawker and inhabitant of Mollar Bosti at Pallabi Slum, the authors found that he willingly gave 1500 taka in every month as space fees to the factory owners. According to him:

"I willingly give money to the factory owners as I am doing business in front of his factory. I know this is a public space, but I gave him money so that he may stand beside me at the time of eviction".

However, the study reveals that among the informal workers about $63.04 \%$ had to give bribe to the police directly and about $18.18 \%$ had to give bribe to the local leaders for using the space as a matter of negotiation. Kamal Hossain, age 24 , a rickshaw puller from Palabi Slum, shared his experiences in this regard:

"I had to give bribe to the Police for pulling the rickshaw in the VIP road. If we disagree to pay, they will snatch away our mattress covers".

Furthermore, sometimes the urban poor had to pay fees to multiple channels so that they can do business without any hindrance. A fisherman from Hindu para Slum at Sattola, named 
Kabir, described how much problematic is doing business in public spaces. In his statement:

"I am at risk of eviction. The space which I am using for doing business has ownership to five people. Currently, I am paying space rent to two owners. Very soon, I may have to pay to all of them. Besides, I am hearing that they are planning to build a multistoried building here. Then it would be tough for me to continue business here and getting a new space for doing business is very problematic and it requires huge money in Dhaka city".

Apart from this, we discovered that, after the eviction, many evictees could reclaim their spaces by negotiating with the local leaders and by giving them bribe as they knew that the eviction was temporary. Although, the people who lacked proper channels and extra money had to leave their temporary places, so they returned back to their villages after the eviction. This mechanism has been described by Bashar Molla, aged 52, who was living at Hindu Para Slum in Sattola in Dhaka for the last 20 years:

"After the eviction, some people left this settlement and they started to live in other slums. Some are seen to live in peripheral areas like Savar and Gazipur. Only a few remained under the open sky because they had close connections with the local leaders and they knew that they could be able to reclaim their space by giving money to the local leaders and mastans".

\section{Claiming the right to the city}

Kalpana's statement clearly denotes the condition of the urban poor - they are being continuously excluded from their right to participation and the decision making process over the production of space, as well as the community life:

"We don't have any right for the betterment of this community. MP Ilias Molla and his fellow men took all decisions here. They never discussed anything with us. Even when they increased the space rent, they never asked for our opinion".

Kalpana Akhter, Houseowner at Pallabi Slum

After doing the survey, the authors explored that about $82 \%$ slum dwellers think that they didn't have any rights in the decision making process over the development of slum communities. The study also reveals that about $76 \%$ slum dwellers never did any protest for claiming their right to the city and about $54 \%$ of them had no voting rights. Besides, their weak engagement with neighbourhood areas (54\% had no connection) and the absence of leadership (16.7\%), and the fear of local leaders and police harassment (18\%) deterred them to claim their rights in and out of the settlements. Again, about $50 \%$ of the respondents feel that doing protests is unnecessary because of their temporality and patterns of work. On an interview with Mehedi Hasan, aged 36 from Pallabi Slum, the authors got the following response:

"We are temporary residents. So what is the necessity of doing a protest?"

On the other hand, while talking with a local government official from Ward No-6, Mirpur-12, we have found similar notions about the urban poor's temporality and the reason they had limited opportunities for them. In his words:

"Most of the slum dwellers are illegal informal citizens. They came to the city for work and after the work they will return back to their villages. Besides, they are not enlisted as citizens by the city corporation. Even, they didn't pay any tax or the necessary bills to the city corporations. So, the government has nothing to do for them except giving them some humanitarian assistance". 
Furthermore, while talking with several slum dwellers, the authors generated the idea that the local leaders forbid them to make any protest because they gave them assurance to reappropriate their spaces after the eviction. Didarul Islam, living in Sattola Slum for the last two decades, confirmed us: "We don't need to do any protest because our local leaders gave us assurance to resettle again". Besides, an interesting finding generated from the quantitative survey showed that about $61 \%$ slum dwellers are satisfied by living in these places. In an interview with Enayet Hossain, aged 30, living in Pallabi Slum at Mirpur, he confirmed us that it is not possible to live in any better places than this, due to his little income:

"It is not possible to live any better places in the city because we have little income. So why will we make a protest?"

Although in some cases it was found that the CBO committee is trying to play some specific roles in the resolution of any conflicting behaviour and of any need or demand of the slum community, but in the name of community development, these informal political leaders accentuate their crisis by depriving the urban poor from their communities.

\section{Discussion}

In Dhaka city, though the livelihood of the urban poor vastly depends on utilizing the public spaces like streets, parks, neighborhood localities, and transportation stations, the state proclaims them and their livelihood activities such as street trading as illegal. As a result, they cannot use any urban grounds on a permanent basis and they are everyday victims of dispossession and displacement. This affects their daily income and it also deprives them from their right to the urban space. From the right to the city perspective, as outlined by Lefebvre (1968), it can be argued that the poor of Dhaka city are unable to appropriate the urban spaces according to their needs. Rather, eviction, displacement, harassment for money, intimidation, uncertainty and even sexual harassment are everyday events for the street vendors, regardless of their gender and sex, when using the urban space. Moreover, as these people severely lack options for settling elsewhere and for other strategies of livelihood, as well as they have very limited power to resist the powerful groups due to lack of tenure security of their livelihood space, they have to adopt strategies to negotiate with them. Therefore, they negotiate with many local state and non state actors like the mastans and policemen by paying them money on a regular basis. It represents a circle of money relations among different middlemen, urban informal power holders and the urban poor, where the state plays an ambivalent and crucial role often by neglecting the real scenario and by continuing this dialect of eviction and repatriation of the urban poor by these unrecognized power holders. This relation is continued through a numbers of formal and informal agents. On one side, the state is denying these people as legal citizens of the city and it is thereby excluding them from the necessary rights over using the urban spaces. On the other side, the state is not evicting the poor from the city permanently and it has allowed many private organizations as well as intermediary actors to sustain the process. The local politicians, mastans, linemen and the police, all have a collective effort so that street vending to be continued by ignoring the higher commands and the necessity to keep the street clear from street trading (Lata et al. 2019). Similarly, with regard to the participation in the decision making of urban affairs from the RTC perspective, it is found that, more than two third of the slum dwellers believe that they do not have any right to participate in the decision making regarding their use of space, as well as other matters of their community life. Moreover, their absence of citizenship identity and voting rights, the less social connection with the neighbors, and the fear of local powerful actors restricted them to participate in any kinds of slum community affairs.

As a result, the urban poor people have accepted such socially embedded power relations arising out of the state's lack of proper policy concern and intention to provide a permanent solution to their problem. So that because many of them believe that they cannot protest as 
they are not legal citizens of the city while the majority of slum dwellers never think to protest. Furthermore, the living slums in Dhaka city have offered them opportunities to work and secured settlements, as the majority have migrated to Dhaka from some other regions of the country for work and to settle their grounds for living (Hossain 2013). These distinctive geographical, social, as well as economic features of Dhaka have offered a peculiar character of the urban poor people as well. Although they are severely deprived from all kinds of state's social services, which are viewed as their rights to the city, they are not organized for demanding their rights to the city. While the existing literature showed the urban poor people's collective and organized efforts for bringing successful right to the city movements in many of the Latin American countries, like Mexico, Brazil, Chile, as well as in some European and South Asian countries (Machabanski 2013, Santos Junior 2014, Adler 2015, Málovics et al. 2019, Vesalon and Crețan 2019), in the case of the urban poor of Dhaka there is hardly any such potential of RTC movements. The lack of leadership, the temporality and the uncertainty of their existence in the city are some of the valid reasons for not claiming their rights. In Delhi, during the recent lockdown due to the Covid-19 pandemic, the government has been compelled to ensure free rations for every poor citizen after implementing a hardcore protest by the poor migrant people. But, in Dhaka, during this pandemic situation, despite having a good allocation from the government, the poor people have rarely availed that opportunities as a result of their unorganized efforts and lack of consciousness over their rights (Recio et al. 2020). Nevertheless, in some cases, the local word councilors have made good efforts to provide reliefs for the destitute and the ultra poor with the assistance of different NGOs. But, the existing urban policies regarding their citizenship are deterring them from accessing goods and services by the state.

From the exiting literature, we also found that wherever the urban poor achieved a successful right to the city movement, such as the case of Roma people in Szeged, Mexican poor people, MPL in Chile and street vendors in India, they were successful with the collective efforts of many non state actors like NGOs and also with the participation of many government officials. But, in Dhaka, the role of such organizations are highly constrained because of the existing powerful political classes whose interests are embedded in the urban space. Although CBO committees are found to be working in many community affairs, their role has been criticised for depriving the poor people from their community affairs. As Castells (2010) defines it, this condition of the local people is represented by social exclusion through which certain individuals and groups are systematically barred from the access to urban services and urban space. The centralization of decision making rights to the powerful class and the depriving local level people of weakened powers deter the higher levels of government and policy planners to claiming the right to the city for the poor in Dhaka (Banks 2008). The poor are always vulnerable because of their meagre livelihood conditions. So, they seek alternative options to negotiate and to secure their livelihoods than protesting on the existing situation (Bohle 2007, Hackenbroch et al. 2016), which further makes them more vulnerable. As a result, the poor people of Dhaka city also engage with everyday social-contract relations with hundreds of state and non-state actors instead of permanently protesting their rights and they rely on them for livelihood security.

\section{Conclusions}

Urban poor people, particularly those who are engaged in the street economy, are the victims of repressive state policies in Dhaka and in many cities in South Asia as well. While in many cities in the world, poor urban people have been successful in accomplishing right to the city movements, the urban poor in Dhaka have prosecuted substitute ways to organize social movements through a range of social relations of exchanging interests among a number of actors. Using the cases of Sattola and Pallabi, this study unfolds the context and the background of poor people's strategies and practices to negotiate with the local powerful 
actors. The poor urban people are involved in everyday street politics over appropriating the urban space with other local actors instead of claiming their rights over that space, although such relations are only securing their livelihood access on a temporary basis. However, this impermanence of livelihood access through processes of displacement and dispossession has established a permanent system of social contacts where poor urban people are sustained within cities with the help of different state and non-state actors. Hence, these social relations are of great hindrance in producing pragmatic strategies to change the urban poor people's condition in cities. Therefore, the role of the civil society in organizing poor people and in increasing their consciousness regarding the rights to the city holds a great importance and it needs to be explored through further research. Furthermore, the government actors played a conciliatory role in changing the urban policies for the poor people in many cities and it also restrained significant potential in facilitating the right to the city movements in Dhaka city. Their roles and potentials in the context of Dhaka need to be assessed in future research.

\section{Acknowledgements}

We would like to thank the two anonymous reviewers and the editor of JURA for their helpful suggestions and advice for improving our paper.

\section{References}

ADLER D. (2015), Do We Have a Right to the City?, Jacobin, Retrieved from: www.jacobinmag.com.

AHMED I. (2014), Factors in building resilience in urban slums of Dhaka, Bangladesh, Procedia Economics and Finance 18, 745-753.

ANDERSON T. (2014), Human development, the state and participation, Development Studies Research 1 (1), 64-74.

AREFIN S. (2018), The Real Estate and Capital Accumulation: An inquiry into Harvey's Model in Dhaka, Peoples' Preface 2 (2), 153-165.

AREFIN S., RASHID T. (2018), Access to Urban Services in the Wave of Neoliberalism: A Study of the Urban Poor in Dhaka, Bangladesh, International Journal of Research and Innovation in Social Science 2 (11), 153-158.

BANKS N. (2008), A tale of two wards: political participation and the urban poor in Dhaka city, Environment and Urbanization 20 (2), 361-376.

BOHLE H.-G. (2007), Geographies of Violence and Vulnerability an Actor-Oriented Analysis of the Civil War in Sri Lanka, Erdkundle 61 (2), 129-146.

BRENNER N., MARCUSE P., MAYER M. (2012), Cities for People, Not for Profit:

Critical Urban Theory and the Right to the City, Routledge, New York. CASTELLS M. (2010), End of Millennium, Volume 3, Wiley-Blackwell, Chichester. \& Kee, London. CENTRE FOR URBAN STUDIES (ed.) (1964), London: aspects of change, MacGibbon COLAU A. (2016), After Habitat III: a stronger urban future must be based on the right to the city, the Guardian, Retrieved from: www.theguardian.com.

CREȚAN R., O'BRIEN T. (2020), Corruption and conflagration: (in)justice and protest in Bucharest after the Colectiv fire, Urban Geography 41 (3), 368-388.

CROSSA V. (2009), Resisting the entrepreneurial city: Street vendors' struggle in Mexico City's historic center, International Journal of Urban and Regional Research 33 (1), 43 63.

ELDEN S. (2007), There is a Politics of Space because Space is Political: Henri Lefebvre and the Production of Space, Radical Philosophy Review 10 (2), 101-116. ETZOLD B., KECK M. (2009), Politics of Space in the Megacity Dhaka: Negotiation of Rules in Contested Urban Arenas, UGEC Viewpoints 2, 13-15.

ETZOLD B., BOHLE H.-G., KECK M., ZINGEL W.-P. (2009), Informality as agency - 
Negotiating food Security in Dhaka, Die Erde 140 (1), 3-24.

FATTAH K. N., WALTERS P. (2020), "A Good Place for the Poor!" Counternarratives to Territorial Stigmatisation from Two Informal Settlements in Dhaka, Social Inclusion 8 (1), 55-65. FERNANDES E. (2007), Constructing the 'Right to the City' in Brazil, Social \& Legal Studies 16 (2), 201-219. GOVERNMENT OF BANGLADESH (2008), Statistical Pocket Book, 2008, Government of Bangladesh Bureau of Statistics, Dhaka. GRILL J. (2012), 'Going up to England': Exploring mobilities among Roma from Eastern Slovakia, Journal of Ethnic and Migration Studies 38 (8), 1269-1287 HACKENBROCH K. (2013a), Negotiating Public Space for Livelihoods: About Risks,

Uncertainty and Power in the Urban Poor's Everyday Life, ERDKUNDE 67 (1), 37-47. HACKENBROCH K. (2013b), The Spatiality of Livelihoods - Negotiations of access to public space in Dhaka, Bangladesh, Franz Steiner Verlag, Stuttgart. HACKENBROCH K., HOSSAIN H. (2012), The organized Encroachment of the Powerful- Everyday Practices of Public Space and Water Supply in Dhaka, Bangladesh, Planning Theory of Practice 13, 397-420. HACKENBROCH K., HOSSAIN S., ALTROCK U., SCHOON S., STERLY H. (2016), Informality, urban governance and the state: negotiations of space in Dhaka and the Pearl River Delta, International Development Planning Review 38 (3), 229-253. HAQUE K. (2012), The Political Economy of Urban Space: Land and Real Estate in

Dhaka City, Institute of Urban Governance Studies, BRAC University, Dhaka. HARVEY D. (1973), Social Justice and the City, Blackwell, Oxford. HARVEY D. (2003), The Right to the City, International Journal of Urban and Regional Research 27 (4), 939-941. HARVEY D. (2004), The 'new' imperialism: accumulation by dispossession, Socialist Register 40,63-87. HARVEY D. (2007), A Brief History of Neoliberalism, Oxford University Press, Oxford. HARVEY D. (2008), The 'Right to the City', New Left Review 53 (Sep/Oct.), 23-40. HARVEY D. (2009), Is This Really the End of Neoliberalism?, CounterPunch+, Retrieved from: www.counterpunch.org. HOLSTON J. (2008), Insurgent Citizenship: Disjunctions of Democracy and Modernity in

Brazil, Princeton University Press, Princeton and Oxford. HOLSTON J. (2011), Contesting Privilege with Right: the Transformation of Differentiated Citizenship in Brazil, Citizenship Studies 15 (3-4), 335-352. HOSSAIN S. (2011), Informal dynamics of a public utility: Rationality of the scene behind a screen, Habitat International 35 (2), 275-285. HOSSAIN S. (2013), Migration, urbanization and poverty in Dhaka, Bangladesh, Journal of the Asiatic Society of Bangladesh 58 (2), 369-382. HOSSAIN S., HACKENBROCH K. (2019), Whose interest finally counts? The statutory production of urban space at the fringes of Dhaka, Bangladesh, Planning Theory 18 (2), 167190.

ISHTIAQUE A., MAHMUD M. S. (2011), Migration objectives and their fulfillment: A micro study of the rural-urban migrants of the slums of Dhaka City, Geografia: Malaysian Journal of Society and Space 7 (4), 24-29. ISLAM N. (2005), Dhaka Now: Contemporary Urban Development, Bangladesh Geographical Society, Dhaka. JHABVALA R. (2010), Foreword, in: Bhowmik S. K. (ed.), Street Vendors in the Global Urban Economy, Routledge, London. LAMA-REWAL S. T. (2011), Women's Right to the City: from safety to citizenship, in: Zérah M.-H., Dupont V., Lama-Rewal S.-T. (eds.), Urban Policies and the Right to the City in India: Rights, Responsibilities and Citizenship, UNESCO, New Delhi, pp. 31-38. LANCIONE M. (2017), Revitalising the uncanny: Challenging inertia in the struggle against forced evictions, Environment and Planning D: Society and Space 35 (6), 1012-1032. LATA L. N. (2020a), Gendered Urban Space in Bangladesh, Global Dialogue 10 (2), 1 - 
4.

LATA L. N. (2020b), Neoliberal Urbanity and the Right to Housing of the Urban Poor in Dhaka, Bangladesh, Environment and Urbanization ASIA 11 (2), 218-230.

LATA L. N. (2020c), To Whom Does the City Belong? Obstacles to Right to the City for the Urban Poor in Bangladesh, Journal of Contemporary Asia, DOl: 10.1080/00472336.2020.1791934.

LATA L., WALTERS P. (2016), The Politics of Space in Dhaka: Informality, Power and Negotiations in the Everyday Life of the Urban Poor, Refereed Proceedings of TASA 2016 Conference - Cities \& Successful Societies, 198-205.

LATA L., WALTERS P., ROITMAN S. (2019), A Marriage of Convenience: Street vendors' everyday accommodation of power in Dhaka, Bangladesh, Cities 84, 143-150.

LEES L., PHILLIPS M. (2018), Handbook of gentrification studies, Edward Elgar, Cheltenham.

LEFEBVRE H. (1968), Le Droit à La Ville, Anthropos, Paris.

LEFEBVRE H. (1991), The Production of Space, Blackwell, Oxford.

LEFEBVRE H. (1996), The Right to the City, in: Kofman E., Lebas E. (eds.), Writings on

Cities: Henri Lefebvre, Blackwell, Cambridge, MA, pp. 147-159.

LEFEBVRE H. (2009), Space: Social Product and Use Value (1979), in: Brenner N.,

Elden S. (eds.), State, Space, World: Selected Essays, University of Minnesota Press, Minneapolis and London, pp. 185-195.

LEY D. (1996), The New Middle Class and the Remaking of the Central City, Oxford University Press, Oxford

MACHABANSKI G. (2013), The Chilean Experience: Struggling for the Right to the City in the Neoliberal Era, University of Illinois, Retrieved from: http://hdl.handle.net/2142/45251.

MACKIE P. K., BROMLEY R. D. F., BROWN A. M. B. (2014), Informal traders and the battlegrounds of revanchism in Cusco, Peru, International Journal of Urban and Regional Research 38 (5), 1884-1903.

MÁlOVICS G., CREȚAN R., MÉREINÉ BERKI B., TÓTH J. (2019), Urban Roma, segregation and place attachment in Szeged, Hungary, Area 51 (1), 72-83.

MARCIL L., AFSANA K., PERRY H. B. (2016), First Steps in Initiating an Effective Maternal, Neonatal, and Child Health Program in Urban Slums: the BRAC Manoshi Project's Experience with Community Engagement, Social Mapping, and Census Taking in Bangladesh, Journal of Urban Health 93, 6-18.

MOHAN S. (2017), Politics of Urban Space: Rethinking Urban Inclusion and the Right to the City, in: Lacey A. (ed.), Women, Urbanization and Sustainability: Practices of Survival, Adaptation and Resistance, Palgrave Macmillan, London, pp. 157-177.

MOHIUDDIN M. (2014), The Real Estate Business in Dhaka City: Growth and Contribution to the Economy of Bangladesh, IOSR Journal of Business and Management 16 (14), 58-60.

PARNELL S., PIETERSE E. (2010), The 'Right to the City': Institutional Imperatives of a Developmental State, International Journal of Urban and Regional Research 34 (1), $146-162$. PHADKE S. (2007), Dangerous Liaisons. Women and Men: Risk and Reputation in Mumbai, Economic and Political Weekly 42 (17), 1510-1518.

PLYUSHTEVA A. (2009), The Right to the City and the Struggles over Public Citizenship: Exploring the links, The Urban Reinventors Online Journal 3 (9), 2-17. PURCELL M. (2002), Excavating Lefebvre: The Right to the City and its Urban Politics of the Inhabitant, GeoJournal 58, 99-108.

PURCELL M. (2003), Citizenship and the Right to the Global City: Reimagining the Capitalist World Order, International Journal of Urban and Regional Research 27 (3), 564-590. RECIO R. B., CHATTERJEE I., LATA L. N. (2020), Covid-19 reveals unequal urban citizenship in Manila, Dhaka and Delhi, LSE Covid-19, Retrieved from: www.blogs.lse.ac.uk. ROEVER S. (2016), Informal trade meets informal governance: Street vendors and legal reform in India, South Africa, and Peru, Cityscape: A Journal of Policy Development and Research 18 (1), 27-46. 
ROKANUZZAMAN M., ALI M. A., HOSSAIN M. N., MIAH M. A. (2013), Study on Livelihood Status of Slum Dwellers in the North Dhaka City Corporation, Journal of Environmental Science and Natural Resources 6 (2), 89-95.

ROSS K. (1988), The Emergence of Social Space: Rimabaud and the Paris Commune (Radical Thinkers), University of Minnesota Press, Minnesota.

ROY T., MARCIL L., CHOWDHURY R. H., AFSANA K., PERRY H. (2014), The BRAC Manoshi Approach to Initiating a Maternal, Neonatal and Child Health Project in Urban Slums with Social Mapping, Census Taking, and Community Engagement, BRAC, Dhaka.

SAMARA T. R., HE S., CHEN G. (2013), Locating Right to the City in the Global South, Routledge, New York.

SANTOS JUNIOR O. A. (2014), Urban common space, heterotopia and the right to the city: reflections on the ideas of Henri Lefebvre and David Harvey, Brazilian Journal of Urban Management 6 (2), 146-157.

SHARP J. P., ROUTLEDGE P., PHILO C., PADDISON R. (eds.) (2000), Entanglements of power: Geographies of domination/resistance, Routledge, London.

SIDDIQUI T. (2008), Migration and gender in Asia, United Nations, Retrieved from: www.un.org.

Boston.

SMITH N., WILLIAMS P. (eds.) (1986), Gentrification of the City, Allen and Unwin,

SWAPAN M. S. H., ZAMAN A. U., AHSAN T., AHMED F. (2017), Transforming Urban Dichotomies and Challenges of South Asian Megacities: Rethinking Sustainable Growth of Dhaka, Bangladesh, Urban Science 1 (4), 31.

TONKISS F. (2005), Space, The City and Social Theory: Social Relations and Urban Forms, Polity Press, Cambridge.

UN-HABITAT (2008), State of the World's Cities 2010/2011: Bridging the Urban Divide, Earth Scan, London and Sterling, VA.

VESALON L., CRET,AN R. (2015), 'We are not the Wild West': anti-fracking protests in Romania, Environmental Politics 24 (2), 288-307.

VESALON L., CREȚAN R. (2019), "Little Vienna" Or "European Avant-Garde City"?

Branding Narratives in a Romanian City, Journal of Urban and Regional Analysis 11 (1), 19-34. Bank, Dhaka. WORLD BANK (2007), Dhaka: Improving living conditions for the urban poor, World

WSUP (2017), Scoping urban sanitation services in three countries, WSUP, Retrieved from: www.wsup.com.

ZÉRAH M.-H., REWAL S. T. L., DUPONT V., CHAUDHURI B. (2011), Right to the City and Urban Citizenship in the Indian Context, in: Zérah M.-H., Dupont V., Lama-Rewal S.-T. (eds.), Urban Policies and the Right to the City in India: Rights, Responsibilities and Citizenship, UNESCO, New Delhi, pp. 1-11.

Initial submission: 29.04.2020

Revised submission: 15.12 .2020

Final acceptance: 28.12.2020

Correspondence: Department of Sociology, Bangabandhu Sheikh Mujibur Rahman Science and Technology University, Gopalganj-8100, Dhaka, Bangladesh.

Email: shams.rehan@bsmrstu.edu.bd 
